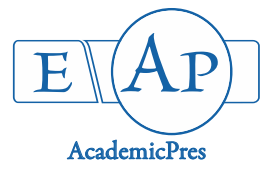

\title{
Antimicrobial Activity of Selected Mosses on Obafemi Awolowo University Campus, Ile-Ife, Nigeria
}

\section{Kehinde O. OLASOJI ${ }^{1 *}$, Amos M. MAKINDE ${ }^{1}$, Bolajoko A. AKINPELU², Oluwatoyin A. IGBENEGHU ${ }^{3}$, Musibau O. ISA ${ }^{1}$}

\author{
${ }^{1}$ Obafemi Awolowo University, Faculty of Science, Department of Botany, Ile-Ife, Osun State, \\ Nigeria; Kennykayy10@gmail.com (*correspondingauthor),makmorak@gmail.com; alamuola25@gmail.com \\ ${ }^{2}$ Obafemi Awolowo University, Faculty of Science, Department of Biochemistry and Molecular Biology, Ile-Ife, Osun State, \\ Nigeria; baakinpelu@gmail.com \\ ${ }^{3}$ Obafemi Awolowo University, Faculty of Pharmacy, Department of Pharmaceutics, Ile-Ife, Osun State, \\ Nigeria; igbeneghuoluwatoyin@gmail.com
}

\begin{abstract}
The present study aimed to evaluate antimicrobial activity of ethanol, methanol, schnapp ( $40 \%$ alcohol), oil palm wine and Raffia palm wine extracts of moss species Archidium ohioense, Pelekium gratum and Hyophila involuta against Bacillus subtilis, Staphylococcus aureus, Escherichia coli, Pseudomonas aeruginosa, Candida albicans and Candida pseudotropicalis. The antimicrobial activities of the alcoholic extracts were tested against selected microorganisms using agar well diffusion method. Minimum inhibitory concentrations (MIC) of the extracts were determined using standard methods. The antimicrobial test of the extracts on selected organisms revealed that the methanolic and ethanolic extracts of the mosses studied were inactive against all the bacteria and fungi screened, while the schnapp, Oil palm wine and Raffia palm wine extracts showed significant activity against the selected organisms. The minimum inhibitory concentration (MIC) value of the extracts on the test organisms ranged from 1.25 to $40 \mathrm{mg} / \mathrm{ml}$. The study concluded that the extracts of the mosses studied contain pharmacologically active constituents which may be responsible for their antimicrobial properties.
\end{abstract}

Keywords: antimicrobial; Archidium obioense; Hyophila involute; Pelekium gratum; phytochemicals

\section{Introduction}

Bryophytes are the second largest group of land plants after flowering plants, which consist of about 15,000 to 25,000 species worldwide and it is divided into three separate divisions, the Marchantiophyta (liverwort), Anthocerotophyta (hornwort) and Bryophyta (mosses) (Gradstein et al., 2001; Asakawa et al., 2013). Bryophytes are known to possess fungi as endobionts, as well as to develop mycorrhiza. However, relationships of bryophytes and fungi remain under-investigated. Bryophytes have been reported to have antifeeding effect and are known to possess various relationships with microorganisms; for example protozoa, fungi, bacteria, algae (Sabovljevic et al., 2001) contain a set of various known and unknown secondary metabolites (Xie and Lou, 2009).

The phytochemical study of bryophytes for pharmaceutical "lead" compounds has been overlooked because of their minuscule nature which makes it difficult to identify and to collect large quantity of pure samples for producing drugs. However, recent studies of some in vitro cultures of bryophytes have shown that they synthesize active substances which are antibiotic (Ilhan et al., 2006; Isa et al., 2014).

Bryophytes produce a broad range of antibiotics and the degree of antibiotic activity within a given species may depend on the age of the gametophyte (Subramoniam and Subhisha, 2005).

Antimicrobial resistance is one of the biggest challenges facing global public health at the beginning of the third millennium. According to World Trade Organization, about 440,000 new cases of multi drug resistant tuberculosis are reported every year, causing at least 150,000 deaths (WHO, 1994). Extract of many bryophytes have been shown to possess varying levels of antimicrobial potential and many chemicals were isolated from them which inhibited the growth of phytopathogenic microorganisms 
(Deora and Narendra, 2007; Deora and Vishwakarma, 2012).

One danger in using bryophytes is that the same compounds that may have antibiotic properties may also be toxic or allergenic, or may be associated with such compounds, thus many antibiotics have been isolated from bryophytes, but few have been developed for medical use, despite their demonstrated effectiveness (Akande, 1992). According to Nweze et al. (2004) the presence of these bioactive components gives them resistance against bacterial, fungal and pathogens. Such bioactive components are said to be responsible for the antimicrobial properties of plant extracts in vitro.

The present study was carried out to investigate the antimicrobial activity of Archidium obioense, Pelekium gratum and Hyophila involuta on some selected microorganisms. The investigation was done with a view to exploring their potentials in manufacturing oral antibacterial drugs that can be used to treat infections caused by the tested organisms.

\section{Materials and Methods}

\section{Collection and identification of plant materials}

The mosses investigated were Archidium obioense Schimp ex. C. Mull, Pelekium gratum (Palis) Jaeg. and Hyophila involuta (Hook) Jaeg.; samples were collected from their natural populations at the Obafemi Awolowo University Campus, Ile-Ife, Nigeria, within Latitudes $7^{\circ} 31^{\prime}$ and $7^{\circ} 34^{\prime} \mathrm{N}$ and Longitudes $4^{\circ} 30^{\prime}$ and $4^{\circ} 32^{\prime} \mathrm{E}$. The plant samples were identified and authenticated at IFE Herbarium of Department of Botany, Obafemi Awolowo University, Ile-Ife, Nigeria.

\section{Sources of microorganisms}

The test organisms employed for screening antimicrobial activities of the plant extracts were Grampositive organisms: Bacillus subtilis (NCTC 8236) and Staphylococcus aureus (ATCC 29213); Gram-negative organisms: Escherichia coli (ATCC 25922), Pseudomonas aeruginosa (ATCC 10145) and yeasts Candida albicans (ATCC 24433) and Candida pseudotropicalis (NCYC 6). All organisms were obtained from the Department of Pharmaceutics, Faculty of Pharmacy of Obafemi Awolowo University, Ile - Ife, Nigeria. The bacteria and yeast were sub-cultured into fresh nutrient agar plates and sabouraud dextrose agar plates respectively for 24 hours before use for antimicrobial test.

Preliminary screening for antimicrobial activity using agar well diffusion method

Duplicate nutrient agar plates were seeded with the test bacteria: Escherichia coli, Staphylococcus aureus, Pseudomonas aeruginosa and Bacillus subtilis organism at 45 ${ }^{\circ} \mathrm{C}$, while Candida albicans and C. pseudotropicalis were prepared using Sabouraud dextrose agar as the culture medium. The plates containing the bacteria and fungi were incubated at $37^{\circ} \mathrm{C}$ and $25^{\circ} \mathrm{C}$ for 20 minutes respectively. Holes of $8 \mathrm{~mm}$ diameter, equidistant to one another, were bored into the plates using sterile cork borer. Three drops of each test sample were introduced into the holes and allowed to diffuse for an hour before incubation for 24 hours. After the incubation time, the presence of clear zones of inhibition around each extract was noted.

\section{(MIC) \\ Determination of minimum inbibitory concentration}

Minimum inhibitory concentrations were determined using the micro broth dilution method as recommended by the Clinical Laboratory Standard Institute (CLSI, 2012). The test was performed in a 96 well micro plate. A volume of $100 \mu \mathrm{l}$ of Mueller Hinton Broth was first dispensed into each well of the plate, then $100 \mu \mathrm{l}$ of sample solution were added into the first well to achieve a concentration of 40 $\mathrm{mg} / \mathrm{ml}$. Serial dilutions $(40,20,10,5,2.5,1.25 \mathrm{mg} / \mathrm{ml})$ were carried out by removing $100 \mu \mathrm{l}$ of reaction medium from the first well into the second well and so on till the tenth well. A volume of $100 \mu \mathrm{l}$ was then withdrawn from the tenth well and discarded. The eleventh well had no test sample, to serve as the negative control, while the twelfth well had ciprofloxacin at $2 \mathrm{mg} / \mathrm{ml}$, as the positive control for antibacterial study; Ketoconazole at $4 \mu \mathrm{g} / \mathrm{ml}$ was added as the positive control for the antifungal study. A volume of 5 $\mu \mathrm{l}$ of the suspension of each test organisms contain approximately $10^{5} \mathrm{cfu} / \mathrm{ml}$ was then added to the respective wells. The last row was not inoculated with any organisms to serve as the un-inoculated control. The experiment was carried out in duplicate and the plates were incubated at 37 ${ }^{\circ} \mathrm{C}$ for 24 hours. After the incubation period, the wells were subcultured onto over dried duplicate Mueller Hinton Agar plates using a multi-inoculator before adding a drop of tetrazolium salt to each well and inspecting for colour change, this indicating the presence of viable cells in the wells. The minimum concentration inhibiting the growth of a test organism was recorded as the MIC of test sample against the organism. For the yeast, the medium used was Sabouraud dextrose medium and the incubation temperature was $25^{\circ} \mathrm{C}$.

\section{Determination of minimum bactericidal/fungicidal} concentration

A multi-inoculator was used to transfer samples of reaction mixture from each well onto fresh duplicate Mueller Hinton agar plates. The plates were incubated at 37 ${ }^{\circ} \mathrm{C}$ for the bacteria and $25^{\circ} \mathrm{C}$ for the yeasts and growth was observed after 72 hours. The wells with the minimum concentration from which no colony was recoverable were taken as indicative of the minimum bactericidal concentration/ fungicidal concentration.

\section{Results}

\section{Antimicrobial investigation}

The antimicrobial activity of the alcoholic extracts (methanol, ethanol, schnapp, oil palm wine and Raffia palm wine) against Escherichia coli, Staphylococcus aureus, Pseudomonas aeruginosa, Bacillus subtilis, Candida albicans, C. pseudotropicalis are shown in Tables 1-5. Both the methanolic and ethanolic extracts of the selected mosses showed no activity against Echerichia coli, Staphylococcus aureus, Pseudomonas aeruginosa, Bacillus subtilis, Candida 
464

albicans and C. pseudotropicalis. All other extracts (schnapp $40 \%$ alcohol, oil palm wine and Raffia palm wine) showed varying degrees of activities against the bacteria and fungi screened.

The minimum inhibitory concentration (MIC), minimum bactericidal concentration (MBC) / minimum fungicidal concentration (MFC) of the extracts were shown in Table 6. All the extracts were either bacteriostatic or bacteriocidal / fungicidal against the microorganisms.
Archidium obioense, Pelekium gratum and Hyophila involuta extracts exhibited different degrees of growth inhibition against the tested bacteria and fungi species. The values of MIC ranged between $1.25-40 \mathrm{mg} / \mathrm{ml}$ and that of MBC were $20-40 \mathrm{mg} / \mathrm{ml}$, while MFC ranged from $1.25-40$ $\mathrm{mg} / \mathrm{ml}$ for all the extracts. Some extracts were not tested because they were not active against the bacteria and fungi during the preliminary screening.

Table 1. Screening of antimicrobial activity of the methanolic extracts of Archidium obioense, Pelekium gratum, Hyophila involuta against different microorganisms

\begin{tabular}{ccccccc}
\hline \multirow{2}{*}{ Mosses/Organism } & \multicolumn{5}{c}{ Activity on selected organisms } \\
\cline { 2 - 6 } & Esc $^{*}$ & Sta $^{*}$ & Bas $^{*}$ & Psa $^{*}$ & Caa $^{\wedge}$ & Cap $^{\wedge}$ \\
\hline Archidium ohioense & - & - & - & - & - & - \\
Pelekium gratum & - & - & - & - & - & - \\
Hyophila involuta & - & - & - & - & NA & NA \\
Ciprofloxacin $2 \mathrm{mg} / \mathrm{ml}$ & + & + & + & + & + \\
$(+$ ve control) & NA & NA & NA & NA & + & + \\
Ketoconazole $4 \mu \mathrm{g} / \mathrm{ml}$ & & & & & \\
$(+$ ve control) & & & & & & \\
\hline
\end{tabular}

Table 2. Screening of antimicrobial activity of the ethanolic extracts of Archidium obioense, Pelekium gratum, Hyophila involuta against different microoganisms

\begin{tabular}{|c|c|c|c|c|c|c|}
\hline \multirow{2}{*}{ Mosses/Organism } & \multicolumn{6}{|c|}{ Activity on selected organisms } \\
\hline & Esc $^{*}$ & $\mathrm{Psa}^{*}$ & Bas $^{*}$ & Sta $^{*}$ & $\mathrm{Caa}^{\wedge}$ & Cap \\
\hline Archidium obioense & - & - & - & - & - & - \\
\hline Pelekium gratum & - & - & - & - & - & - \\
\hline Hyophila involuta & & & & & & \\
\hline Ciprofloxacin $2 \mathrm{mg} / \mathrm{ml}$ & - & - & - & - & - & - \\
\hline (+ve control) & + & + & + & + & NA & NA \\
\hline $\begin{array}{l}\text { Ketoconazole } 4 \mu \mathrm{g} / \mathrm{ml} \\
\text { (+ve control })\end{array}$ & NA & NA & NA & NA & + & + \\
\hline
\end{tabular}

Key:

Esc = Escherichia coli; Bas = Bacillus subtilis; Sta = Staphylococcus aureus; Psa = Pseudomonas aeruginosa Caa = Candida albicans; Cap = Candida pseudotropicalis;

${ }^{*}=$ Bacteria, $\stackrel{\wedge}{=}$ fungi, $\quad+=$ Presence of activity, $\quad-=$ Absence of activity, NA - Not Applicable

Table 3. Screening of antimicrobial activity of the schnapp extracts of Archidium obioense, Pelekium gratum, Hyophila involuta against different microorganisms

\begin{tabular}{|c|c|c|c|c|c|c|}
\hline \multirow{2}{*}{ Mosses/Organism } & \multicolumn{6}{|c|}{ Activity on selected organisms } \\
\hline & Esc $^{*}$ & $\mathrm{Psa}^{*}$ & Bas* & $\mathrm{Sta}^{*}$ & $\mathrm{Caa} \wedge$ & Cap^ \\
\hline Archidium obioense & - & - & + & + & - & - \\
\hline Pelekium gratum & - & - & + & + & + & + \\
\hline Hyophila involuta & - & - & + & + & + & + \\
\hline Ciprofloxacin $2 \mathrm{mg} / \mathrm{ml}$ (+ve control) & + & + & + & + & NA & NA \\
\hline Ketoconazole $4 \mu \mathrm{g} / \mathrm{ml}$ (+ve control) & NA & NA & NA & NA & + & + \\
\hline
\end{tabular}

Table 4. Screening of antimicrobial activity of the Oil palm wine extracts of Archidium obioense, Pelekium gratum, Hyophila involuta against different microorganisms

\begin{tabular}{|c|c|c|c|c|c|c|}
\hline \multirow{2}{*}{ Mosses/Organism } & \multicolumn{6}{|c|}{ Activity on selected organisms } \\
\hline & $\operatorname{Esc}^{*}$ & $\mathrm{Psa}^{*}$ & Bas* $^{*}$ & $\mathrm{Sta}^{*}$ & $\mathrm{Caa}^{\wedge}$ & Cap \\
\hline Archidium obioense & + & + & + & + & - & - \\
\hline Pelekium gratum & + & + & + & + & - & - \\
\hline Hyophila involuta & + & + & + & + & - & - \\
\hline Ciprofloxacin $2 \mathrm{mg} / \mathrm{ml}$ (+ve control) & + & + & + & + & NA & NA \\
\hline Ketoconazole $4 \mu \mathrm{g} / \mathrm{ml}$ (+ve control) & NA & NA & NA & NA & + & + \\
\hline
\end{tabular}

Key:

Esc $=$ Escherichia coli; Bas = Bacillus subtilis; Sta = Staphylococcus aureus; $\mathrm{Psa}=$ Pseudomonas aeruginosa $;$ Caa = Candida albicans; Cap = Candida pseudotropicalis;

${ }^{*}=$ Bacteria, $\stackrel{\wedge}{=}$ fungi, $\quad+=$ Presence of activity, $\quad-=$ Absence of activity, NA - Not Applicable 
Table 5. Screening of antimicrobial activity of the Raffia palm wine extracts of Archidium obioense, Pelekium gratum, Hyophila involuta against different microorganisms

\begin{tabular}{ccccccc}
\hline \multirow{2}{*}{ Mosses/Organism } & \multicolumn{7}{c}{ Activity on selected organisms } \\
\cline { 2 - 7 } & Esc $^{*}$ & Psa $^{*}$ & Bas $^{*}$ & Sta $^{*}$ & Caa $^{\wedge}$ & Cap $^{\wedge}$ \\
\hline Archidium ohioense & + & + & + & + & - & - \\
Pelekium gratum & - & - & - & - & + & - \\
Hyophila involuta & - & - & - & - & + & - \\
Ciprofloxacin $2 \mathrm{mg} / \mathrm{ml}$ (+ve control) & + & + & + & + & NA & NA \\
Ketoconazole $4 \mathrm{~kg} / \mathrm{ml}$ (+ve control) & NA & NA & NA & NA & + & + \\
\hline
\end{tabular}

Key:

Esc = Escherichia coli; Bas = Bacillus subtilis; Sta = Staphylococcus aureus; $\mathrm{Psa}=$ Pseudomonas aeruginosa $;$ Caa = Candida albicans; Cap = Candida pseudotropicalis;

${ }^{*}=$ Bacteria,$\stackrel{\wedge}{=}$ fungi, $\quad+=$ Presence of activity, $\quad-=$ Absence of activity, NA - Not Applicable

Table 6. The minimum inhibitory concentration (MIC) $\mathrm{mg} / \mathrm{ml}$, minimum bactericidal concentration (MBC) $\mathrm{mg} / \mathrm{ml}$ and minimum fungicidal concentration (MFC) $\mathrm{mg} / \mathrm{ml}$ of alcoholic extracts of $A$. obioense, P. gratum, H. involuta

\begin{tabular}{|c|c|c|c|c|c|c|c|c|c|c|c|c|}
\hline \multirow{2}{*}{$\begin{array}{l}\text { Bacteria/plant } \\
\text { extracts }\end{array}$} & \multicolumn{2}{|c|}{ E. coli } & \multicolumn{2}{|c|}{$P$. aeruginosa } & \multicolumn{2}{|c|}{ B. subtilis } & \multicolumn{2}{|c|}{ S. aureus } & \multicolumn{2}{|c|}{ C. albicans } & \multicolumn{2}{|c|}{ C.pseudotropicalis } \\
\hline & MIC & $\mathrm{MBC}$ & MIC & $\mathrm{MBC}$ & MIC & $\mathrm{MBC}$ & MIC & $\mathrm{MBC}$ & MIC & MFC & MIC & MFC \\
\hline $\begin{array}{l}\text { Pelekium gratum } \\
\text { (schnapp) }\end{array}$ & NT & NT & NT & NT & 1.25 & $>40$ & 5.0 & 20 & 20 & 20 & 1.25 & 1.25 \\
\hline $\begin{array}{l}\text { Archidium obioense } \\
\text { (schnapp) }\end{array}$ & NT & NT & NT & NT & 2.50 & $>40$ & 5.0 & $>40$ & NT & NT & NT & NT \\
\hline $\begin{array}{l}\text { Hyophila involuta } \\
\text { (schnapp) }\end{array}$ & NT & NT & NT & NT & 1.25 & $>40$ & 2.50 & 20 & 20 & 20 & 5.0 & 5.0 \\
\hline $\begin{array}{l}\text { Hyophila involuta } \\
\text { (Oil palm wine) }\end{array}$ & 10 & 20 & 20 & 20 & 40 & $>40$ & 10 & $>40$ & NT & NT & NT & NT \\
\hline $\begin{array}{l}\text { Archidium obioense } \\
\text { (Oil palm wine) }\end{array}$ & 20 & 20 & 20 & 20 & 20 & $>40$ & 10 & 40 & NT & NT & NT & NT \\
\hline $\begin{array}{l}\text { Pelekium gratum } \\
\text { (Oil palm wine) }\end{array}$ & 40 & 40 & 40 & $>40$ & $>40$ & $>40$ & 40 & $>40$ & NT & NT & NT & NT \\
\hline $\begin{array}{l}\text { Archidium obioense } \\
\text { (Raffia palm wine) }\end{array}$ & 20 & $>40$ & 40 & $>40$ & 40 & $>40$ & 40 & $>40$ & NT & NT & NT & NT \\
\hline $\begin{array}{l}\text { Hyophila involuta } \\
\text { (Raffia palm wine) }\end{array}$ & NT & NT & NT & NT & NT & NT & NT & NT & 40 & $>40$ & NT & NT \\
\hline $\begin{array}{l}\text { Pelekium gratum } \\
\text { (Raffia palm wine) }\end{array}$ & NT & NT & NT & NT & NT & NT & $\mathrm{NT}$ & NT & 40 & $>40$ & NT & NT \\
\hline
\end{tabular}

Key:

$\mathrm{NT}=$ not tested; $\mathrm{MIC}=$ Minimum Inhibitory Concentration; $\mathrm{MBC}=$ Minimum Bactericidal Concentration; $\mathrm{MFC}=$ Minimum Fungicidal Concentration

\section{Discussion}

Microbiological tests carried out in the hereby study showed that different bryophytes possess different influence on the growth of microorganisms. Other investigator's report on the antimicrobial properties of bryophytes implies that these mosses could be used as an alternative for the treatment of infections that could be caused by these microorganisms (Isa et al., 2014; Deora and Suhalka, 2016). The result of the extracts from the selected moss studied has varied antibacterial and antifungal activities against the test organisms, except the methanol and ethanol extracts that showed no activity. The possible reason for the data obtained might be varying solubility of various plant metabolites in different solvents (Aibinu et al., 2007). It also suggests that the extracts of this plant are broad spectrum in their activities and this agrees with the observation of previous workers that plants contain substances that are antimicrobial (Olukoya et al., 1986).

The implication of the broad spectrum action of some of these extracts is that they can be used in antiseptic and disinfectant formulation, as well as in chemotherapy if the active ingredients are isolated (Olukoya et al., 1993). The resistance shown by some of the tested organisms to some of the extracts e.g. methanol and ethanol extracts of Archidium obioense, Pelekium gratum, Hyophila involuta on all the microorganisms screened, should not be seen as absence of antibiotic activity in those extracts, but it may be that the concentration used was too low to inhibit the growth of the organisms or are probably potent against other microorganisms (Isa et al., 2014).

In the current study, all the extracts of mosses showed more antibacterial activity than antifungal activity, and this concur with the work of Ertuk et al. (2015) who investigated the antifungal, antibacterial and antioxidant activity of 8 different acrocarpous mosses which were tested in vitro against 13 different microorganisms and 3 yeast strains; the authors reported that all crude extracts from mosses showed more antibacterial activity compared with antifungal activity. Also, from the study there is a clear indication that the solvent system plays a significant role in the solubility of the active principles in the plant and also influences antibacterial activities. This also indicates that different solvents have different polarities, dispersibility and penetrability and could selectively extract different phytochemicals (Zhang, 2015). 
466

The antimicrobial test conducted hereby revealed that the oil palm wine extracts of these mosses had high activity against the bacteria screened. This implies that the use of palm wine as a solvent possibly releases some active ingredients which have high activity against some enteric organisms. This agrees with the work of Aibinu et al. (2007) who investigated the potency of Citrus aurantifolia (lime fruit) against pathogens using five different solvents as extractants (distilled water, schnapps, ethanol, Palm wine, fermented water from three days soaked ground maize). The researchers reported that apart from the lime oil, Palm wine extract had the highest activity against both grampositive and gram-negative isolates and this was closely followed by the schnapps extract and ethanol extract and then aqueous extract and lime juice.

The present study also showed that Candida albicans and Candida pseudotropicalis were most sensitive to schnapp extracts of Pelekium gratum and Hyophila involuta. The results obtained are similar to some researchers' report that extracts from mosses displayed anti-fungal activities (Bodade et al., 2008). In the study, Baccilus subtilis and Staphylococcus aureus (Gram-positive bacteria) were found to be more sensitive to the extracts than $E$. coli and Pseudomonas aeruginosa (Gram-negative bacteria). The cell wall of Gram-positive bacteria is less chemically complex than that of the Gram-negative bacteria (Lamikanra, 2010). Excellent antimicrobial activities were observed for oil palm wine and schnapp extracts of the studied mosses which may be due to their low MIC and MBC/MFC values. According to El-Mahmood (2009) antimicrobial agents with low activity against a particular organism usually gives high minimum inhibitory concentrations (MIC) and minimum bactericidal concentrations (MBC) or minimum fungicidal concentrations (MFC) values, while a highly reactive agents gives low MIC and MBC/MFC values.

\section{Conclusions}

The investigated mosses can therefore be used to source for antibacterial drugs that can treat infections caused by the susceptible micro-organisms. In the presents study, the microbiological investigations carried out on several moss species have shown activity coherent with their use in medicine and also as a pointer to new source of novel drugs.

\section{Conflict of Interest}

The authors declare that there are no conflicts of interest related to this article.

\section{References}

Aibinu I, Adenipekun T, Adelowotan T, Ogunsanya T, Odugbemi, T (2007). Evaluation of the antimicrobial properties of different parts of Citrus aurantifolia (Lime fruit) as used locally. African Journal of Traditional, Complementary and Alternative Medicines 4(2):185-190. Akande AO (1992). A description and provisional key to some mosses in Ondo State, Nigeria Nigerian Journal of Botany 5:145-160.

Asakawa Y, Ludwiczuk A, Nagashima F (2013). Chemical constituents of bryophytes: bio- and chemical diversity, biological activity, and chemosystematics. Springer Science and Business Media. Vienna, Austriapp796.
Bodade RG, Bokar PS, Arfeen MS, Khobragadi, CN (2008). In-vitro screening of bryophytes for antimicrobial activity. Journal of Medicinal Plants 7(4):310-319.

CSLI (2012). Clinical and laboratory standard institute. Performance standard for antimicrobial susceptibility testing: twenty-second information supplement M100-S22. CSLI, Wayne, PA, USA.

Deora GS, Narendra JS (2007). Antibiotic effects of certain bryophytes on Agrobacterium tumifaciens. Journal of Pure and Applied Microbiology 1(2):215-219.

Deora GS, Suhalka D (2016). Phytochemical composition and fungicidal potential of moss Philonotis revoluta against spore germination process offungus Helminthosporium turcicum. Journal of Pharmacy and Biological Sciences 11(6):38-43.

Deora GS, Vishwakarma G (2012). Phytochemical screening and antimicrobial activity of Plagiochasma intermedium. Journal of Pure and Applied Microbiology 6(2):869-874.

El-Mahmood AM (2009). Antibacterial activity of crude extracts of Euphorbia birta against some bacteria associated with enteric infections. Journal of Medicinal Plants Research 3(7):498-505.

Ertuk O, Sahin H, Ertuk YE, Hotaman EH, Koz B, Ozdemir O (2015). The antimicrobial and antioxidant activities of extracts obtained from some moss speciesin Turkey. Herba Polonica 61(4):52-65.

Gradstein SR, Churchill SP, Salazar Allen N (2001). Guide to the bryophytes of tropical America. Memoirs of the New York Botanical Garden 86:1-577.

Ilhan S, Savaroglu F, Çolak F, Isçen C, Erdemgil F (2006). Antimicrobial activity of Palustriella commutata (Hedw.) ochyra extracts (Bryophyta). Turkish Journal Biology 30(3):149-152.

Isa MO, Makinde AM, Akinpelu BA (2014). Secondary metabolites and antimicrobial activity of selected mosses at Obafemi Awolowo University, Ile - Ife, Nigeria. International Journal of Scientific Research 4(1):49-60.

Lamikanra A (2010). Essential microbiology for students and practitioner of pharmacy, medicine and microbiology. $2^{\text {nd }}$ edition. Amkrabooks.

Nweze EL, Okafor JI, Njoku O (2004). Antimicrobial activities of methanolic extracts of Tremaguineensis (Schumn and Thorn) and Morindalucida Benth used in Nigeria. Biological Research 2(1):39-46.

Olukoya DK, Ndika N, Odugbemi TO (1993). Antibacterial activity of some medicinal plants in Nigeria.Journal of Ethnopharmacology 39(1): 69-72.

Olukoya DK, Odugbemi TO, Bamgbose SOA (1986). Some aspects of traditional therapy of Gonorrhea in Lagos, Nigeria. Journal of Research in Ethno-Medicine 1:26-29.

Sabovijevic M, Ganeva A, Tsakiri E, Stefanut S (2001). Bryology and bryophyte protection in South-eastern Europe. Biological Conservation 101(1):73-84.

Subramoniam A, Subhisha S (2005). Bryophytes of India: a potential source of antimicrobial agents. In: Khan A and Khranum A, editor. Role of biotechnology in medicinal and aromatic plants. Vol. II Hyderabad, India: Ukaaz publication.

Xie CF, Lou HX (2009). Secondary metabolites in some bryophytes. An ecological aspect. Chemistry and Biodiversity 6(3):303-312.

Zhang Q (2015). Effects of extraction solvents on phytochemicals and antioxidant activities of walnut (Juglans regia $\mathrm{L}$.) green husk extracts European Journal of Food Science and Technology 3(5):15-21. 